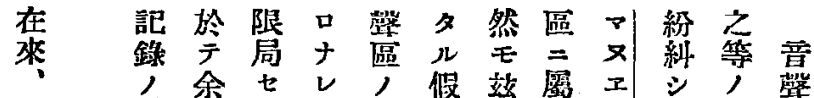

意方公ラト區說心

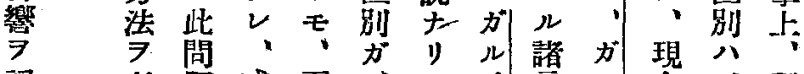

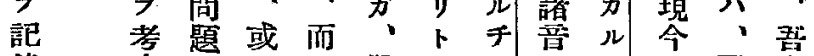

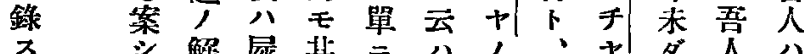

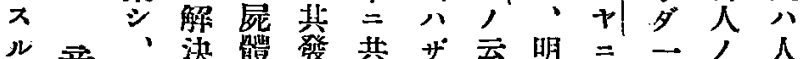

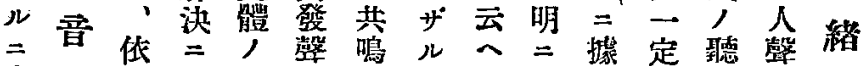

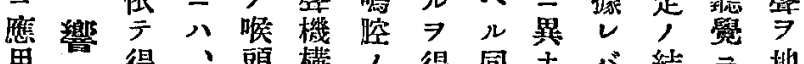

用得、頭棈了得同ナバ結

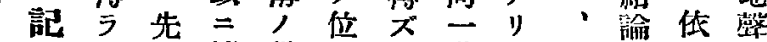

鏻

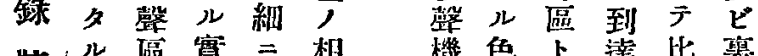

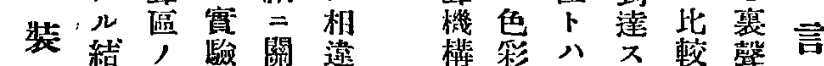

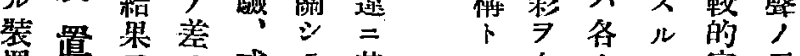

䈯 $\Rightarrow$ 或

演本八公、基同至易種

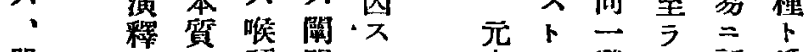

單的 $\exists$ 頭明 来云發 $ス$ 認篇

三

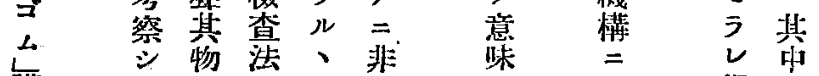

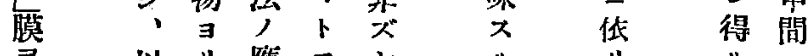

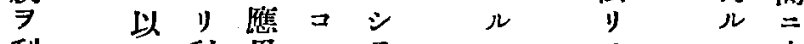

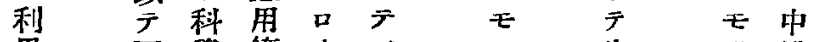

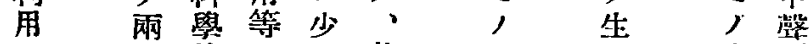

七者的: 其

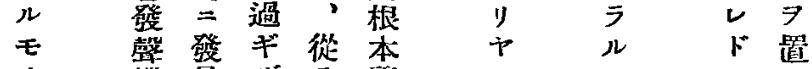

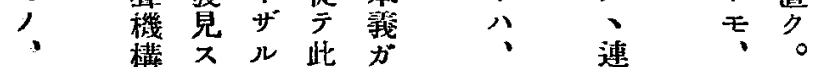

i)

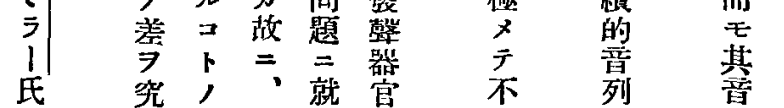

氏 究, 就官查奛列堷

ᄀ 2 徑多, 物名學

7 卜 逐研 $=$ 程的

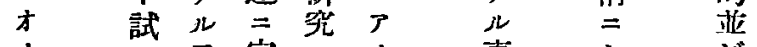

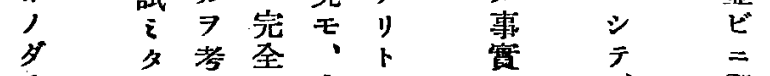

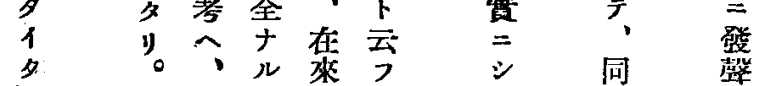

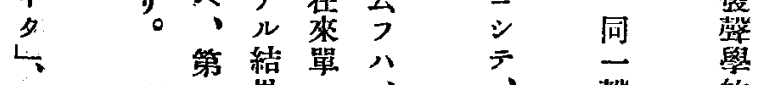

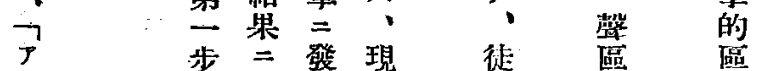

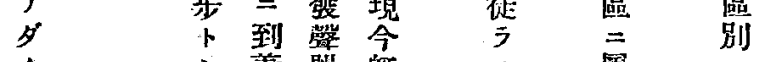

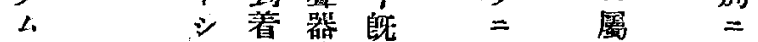

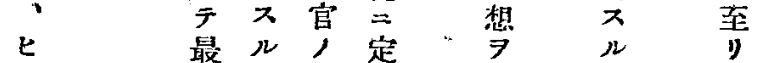

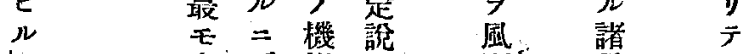

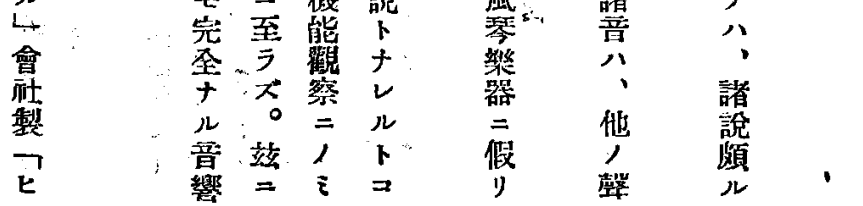

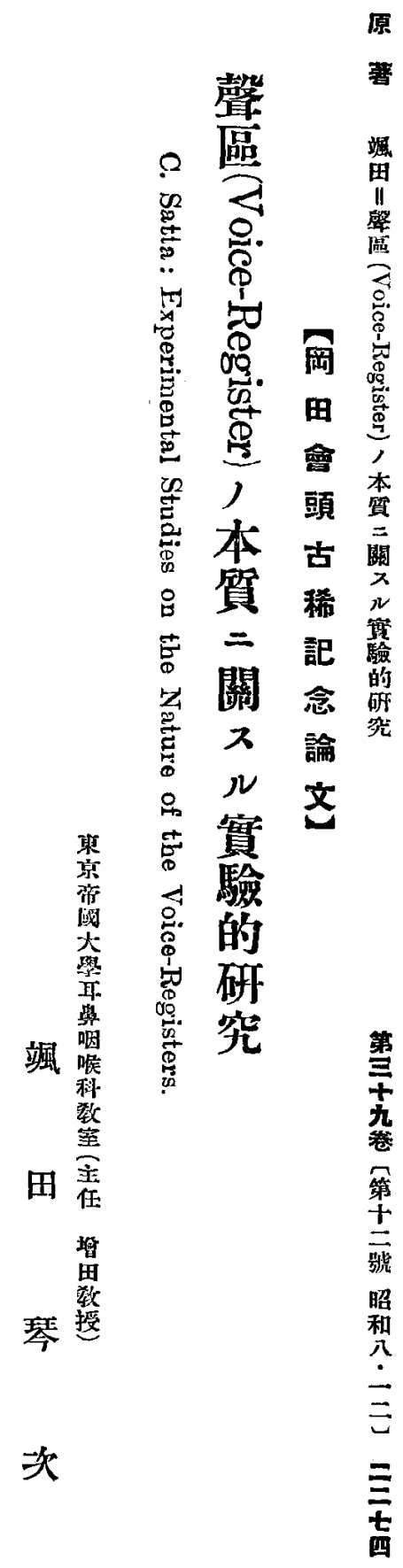




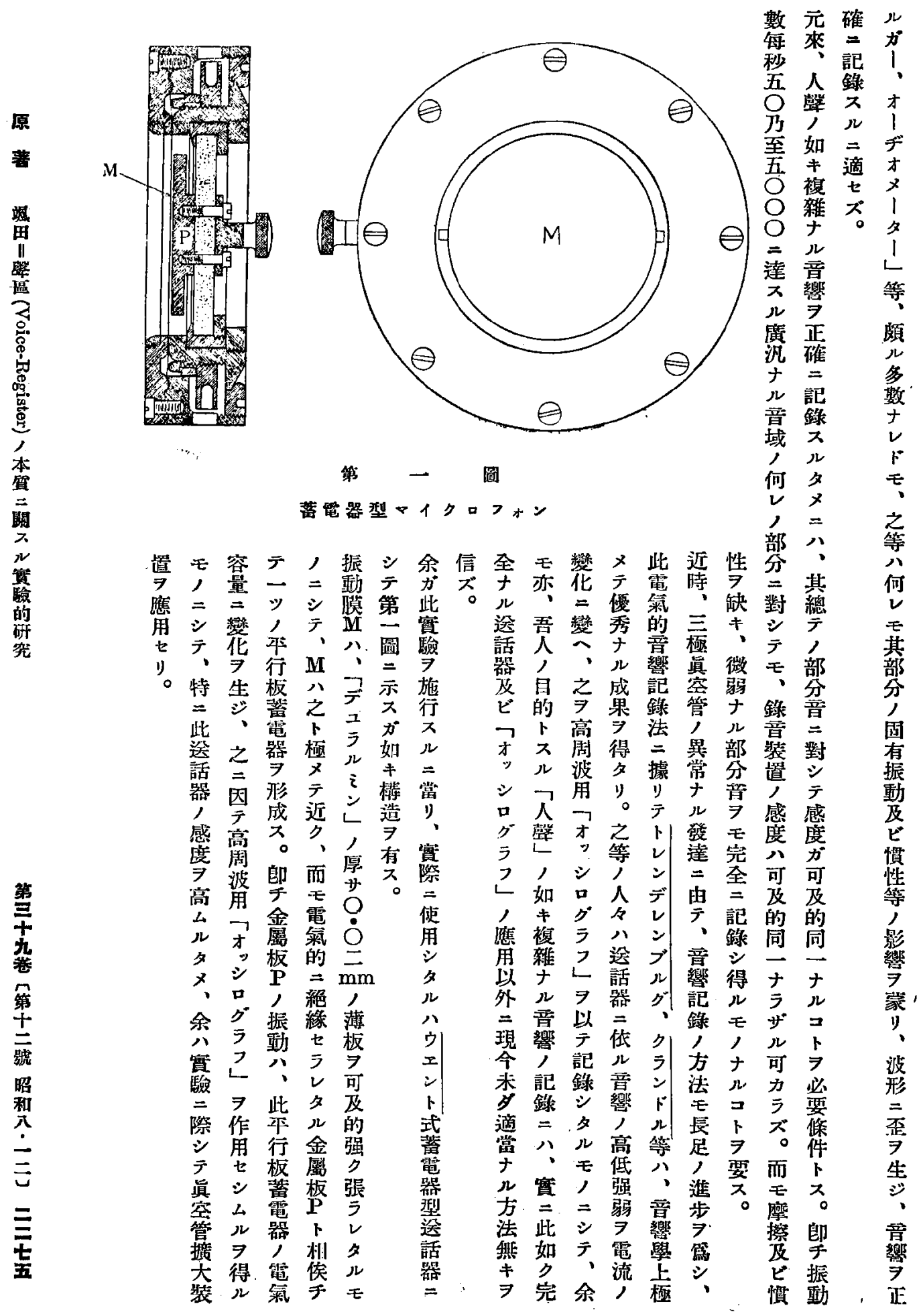




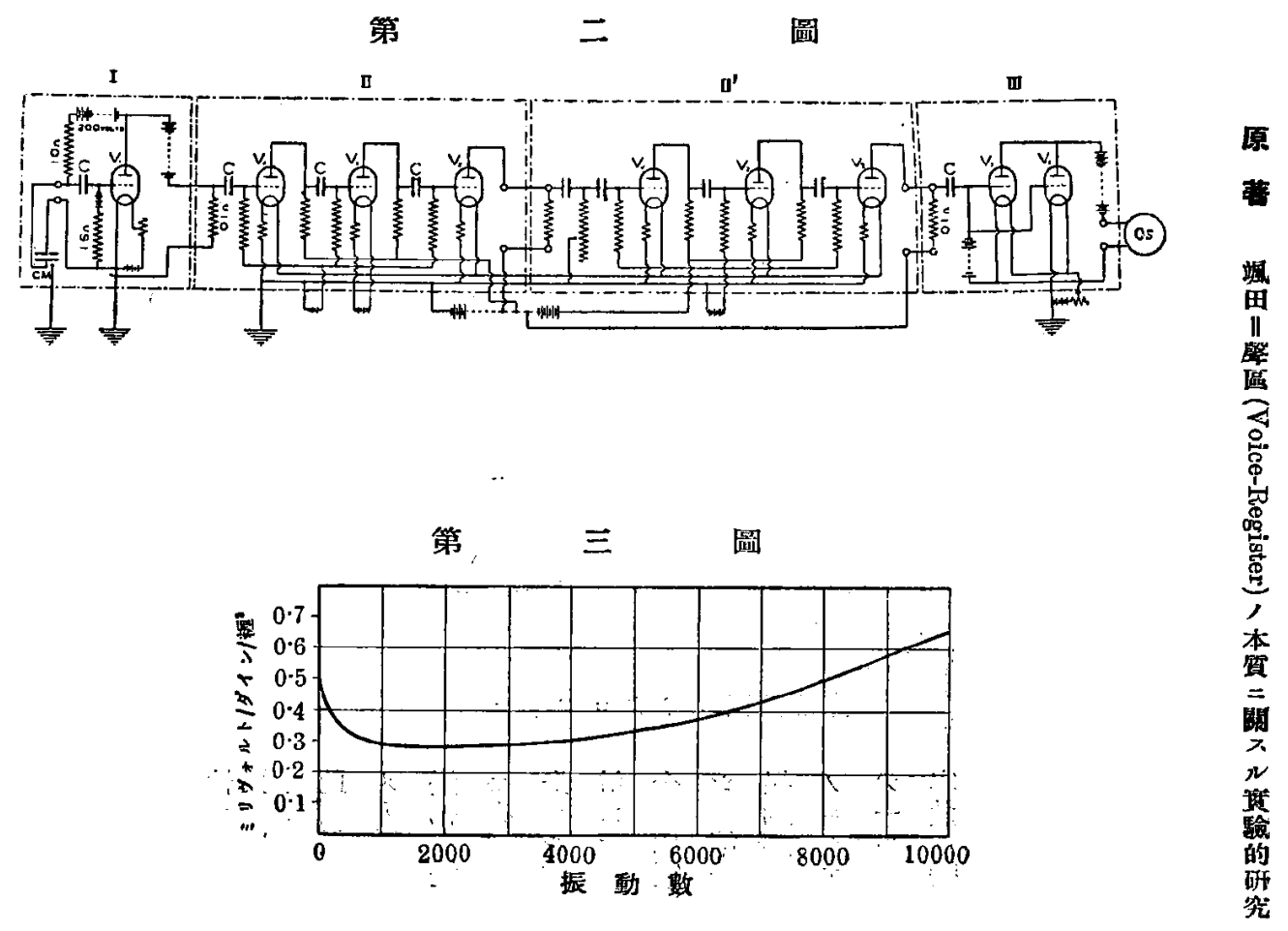

瑟電器型マイクロフォン周波特性

(感宽と振動數との關保)

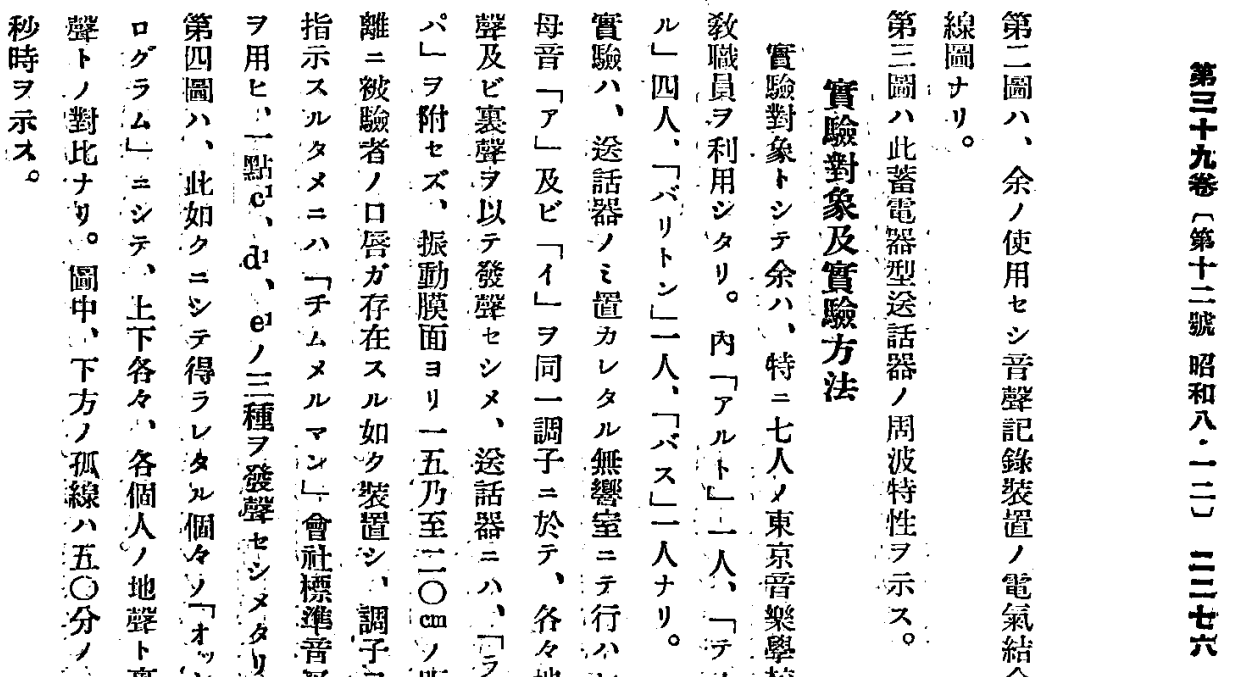




$$
\begin{aligned}
& \text { 第四，噣 } \\
& \text { (I) }
\end{aligned}
$$
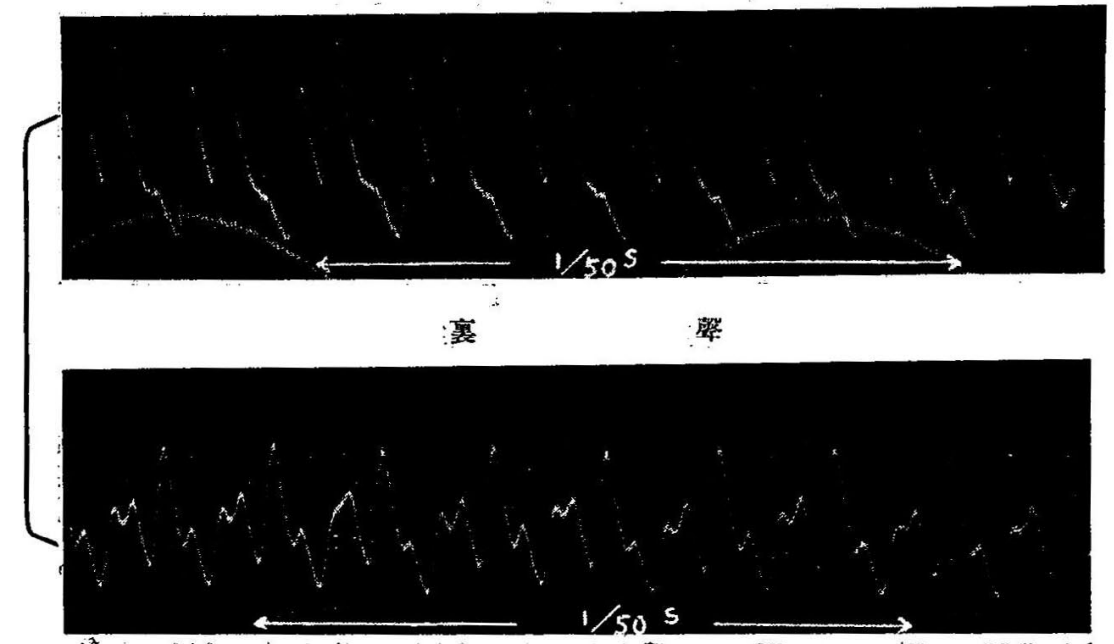

(II)

M. K. (Tenor)

舟要( $>)^{\prime}$ 諴子[ $\left.\mathrm{c}^{\prime}\right] \mathrm{n}=256$

地

慗

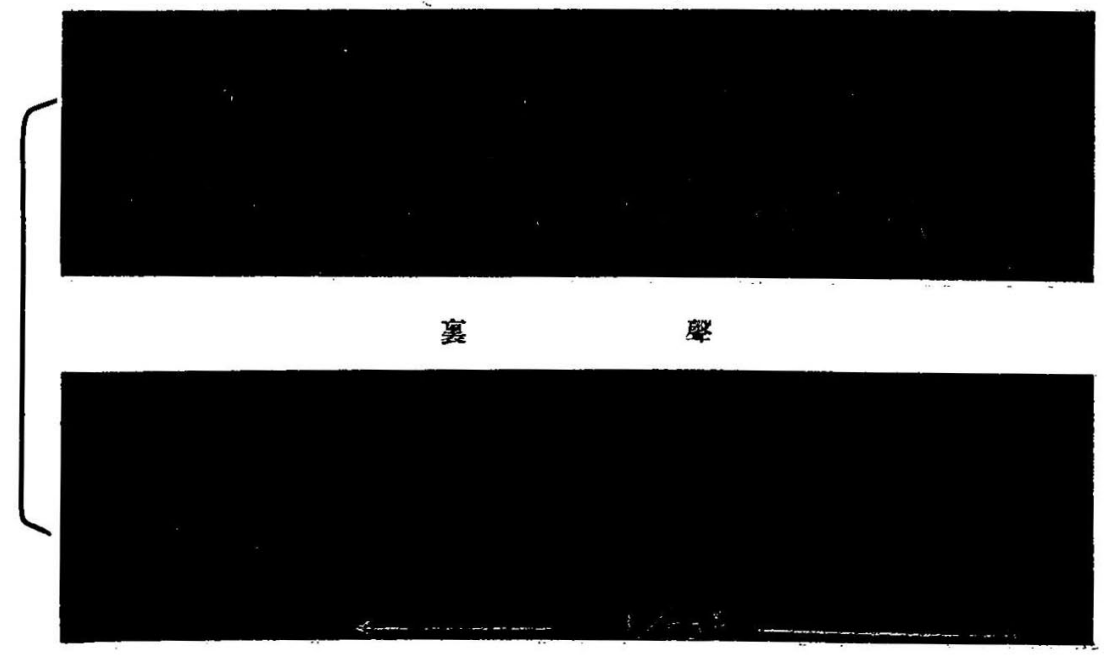



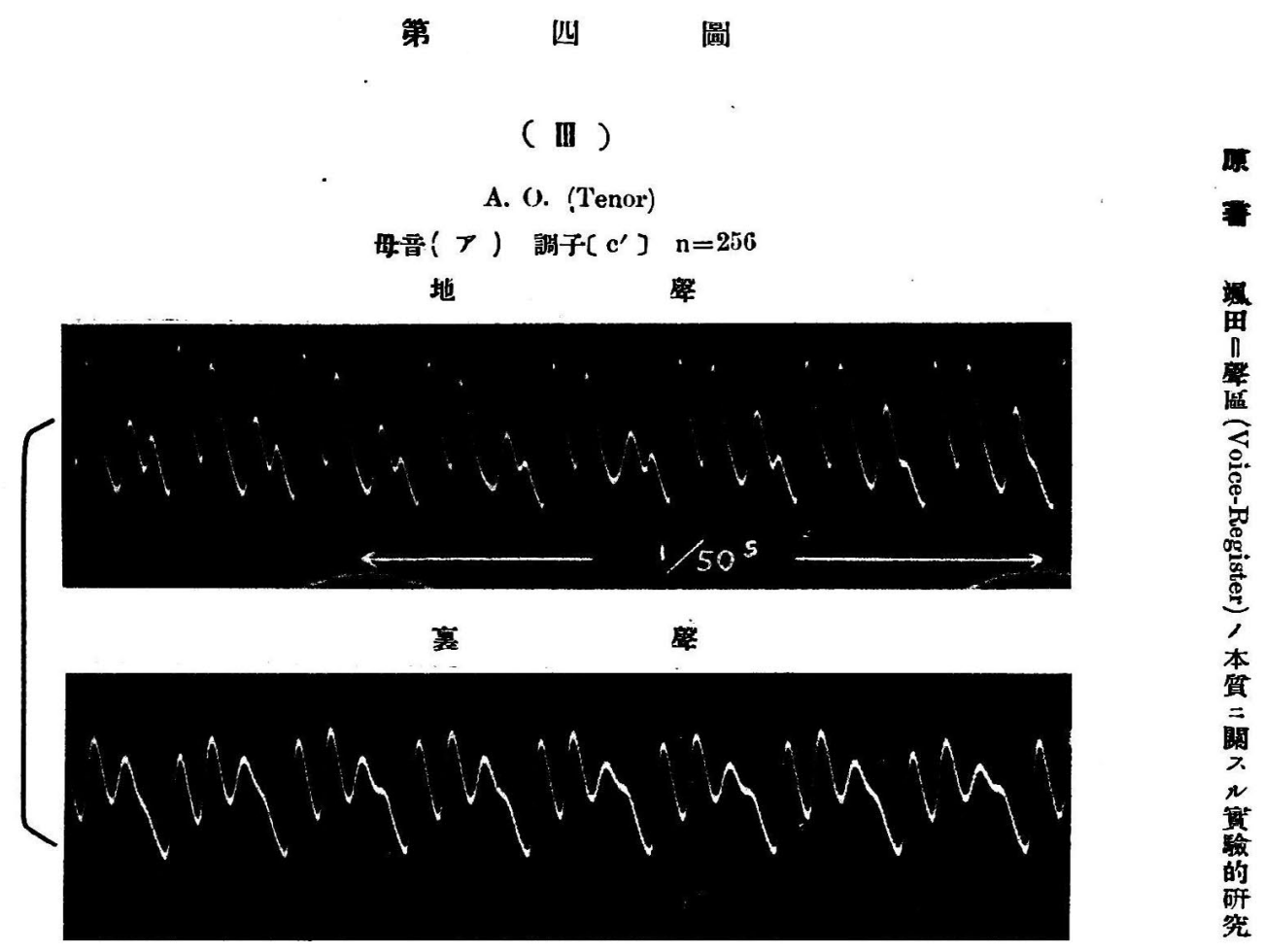

\section{( $\mathbf{N})$}

H. S. (Alto)

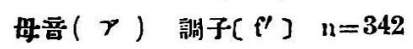

地拏

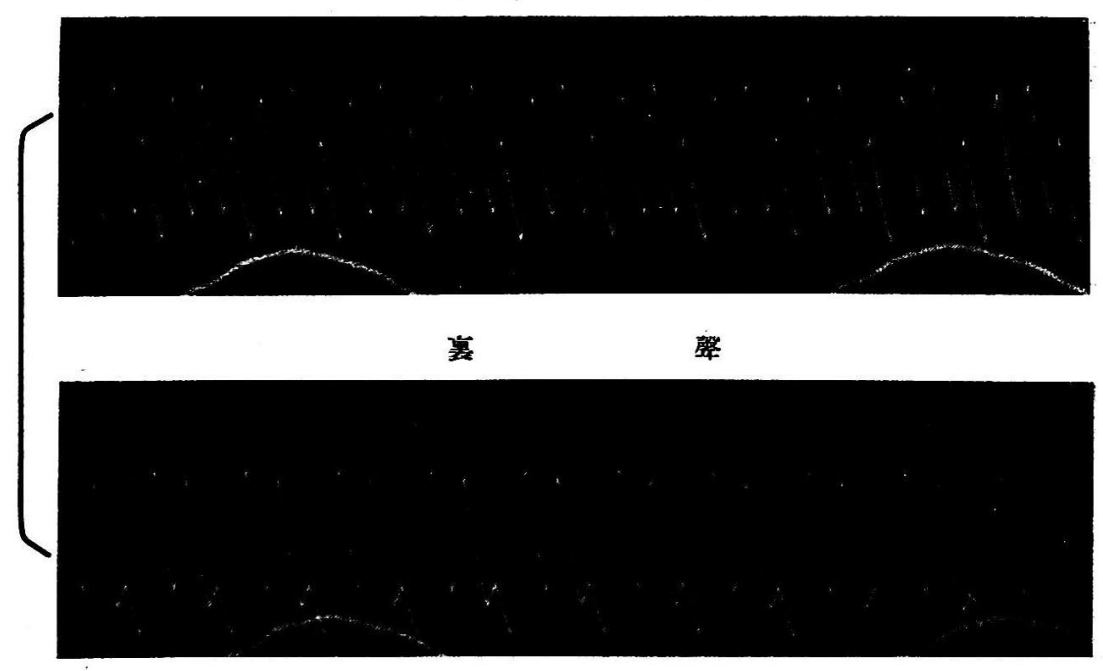




$$
\begin{aligned}
& \text { 第四喝 } \\
& \text { ( V) }
\end{aligned}
$$

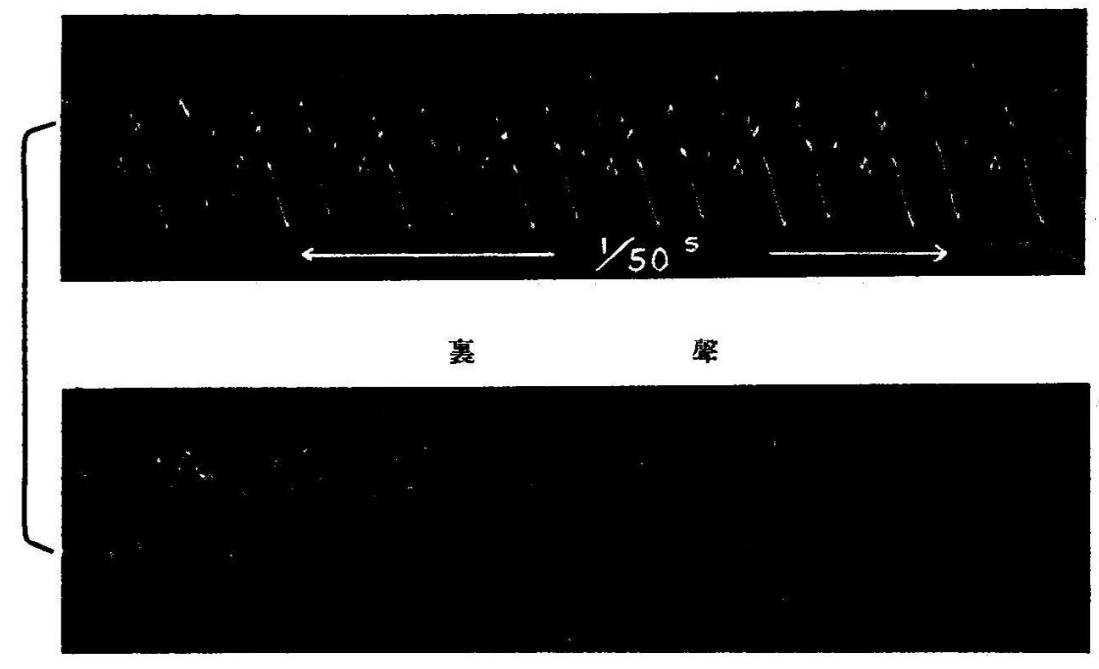

\section{( VI )}

s. S. (Bariton)

冓豆（1） 調子[ $\left.\mathrm{e}^{\prime}\right] \mathrm{n}=323$

地

㢣

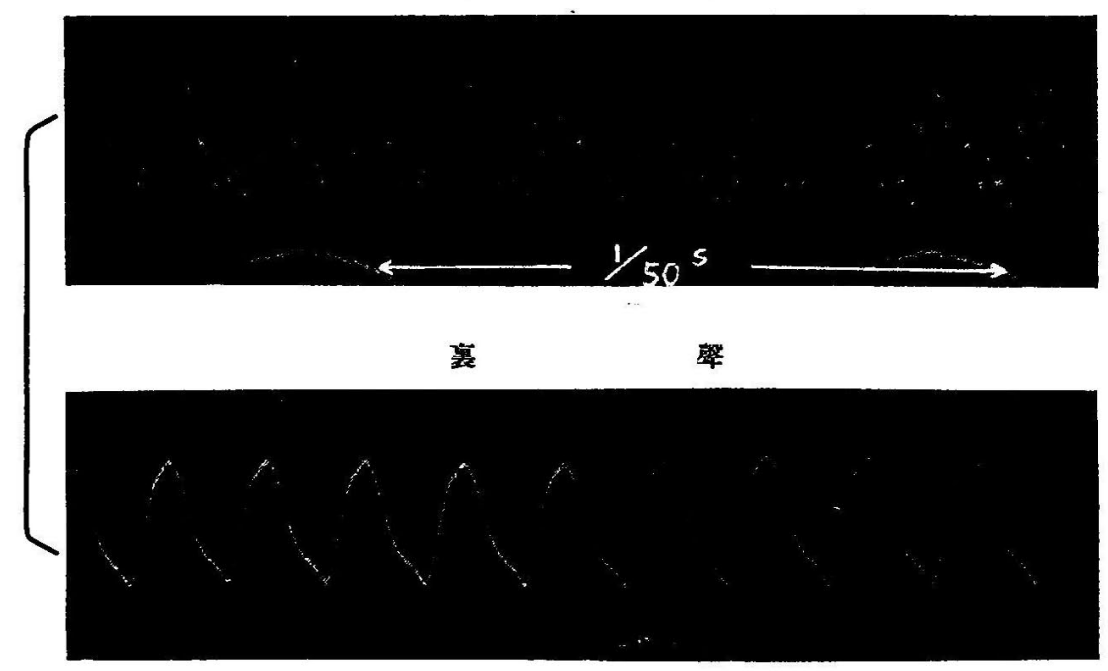




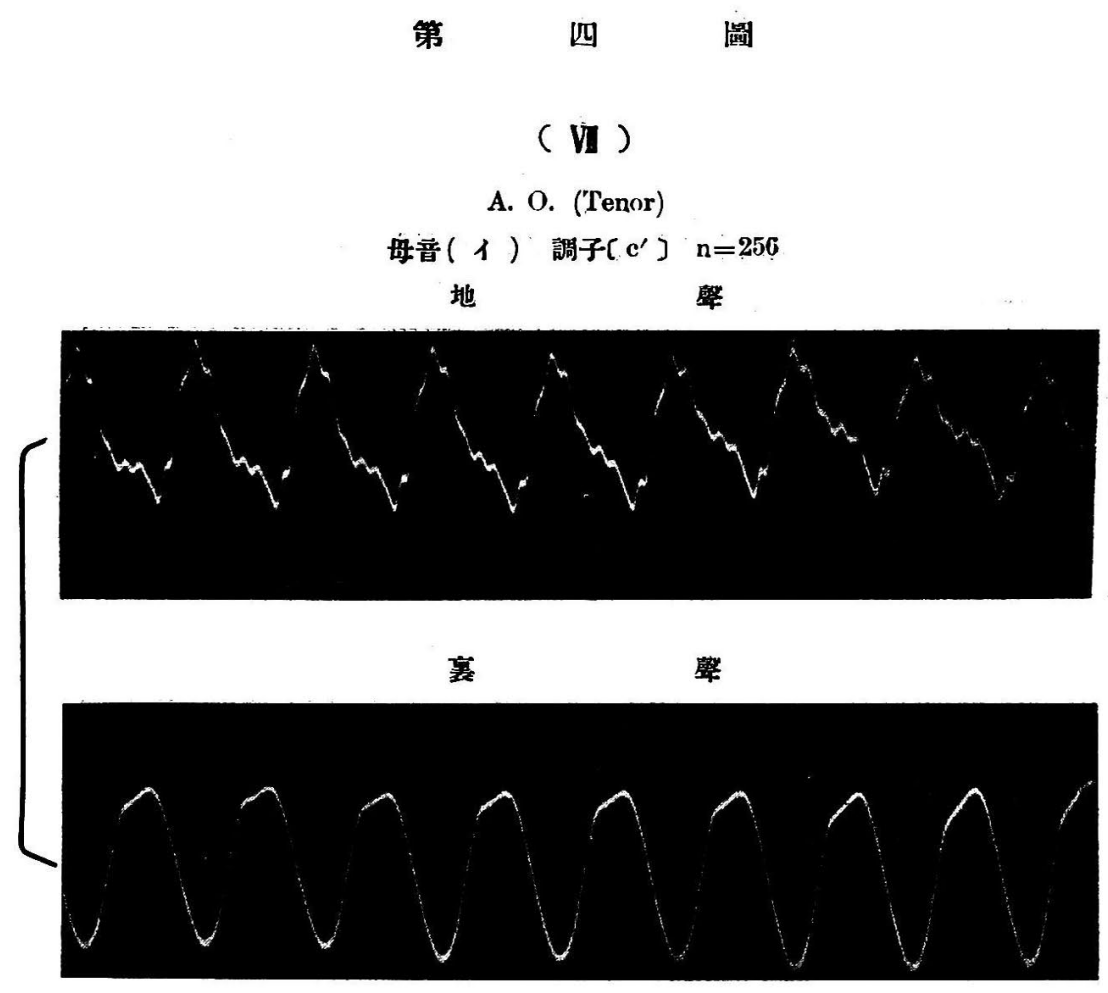

舟音（1）調子[ $\left.\mathbf{c}^{\prime}\right] \mathrm{n}=\mathbf{2 5 6}$ 

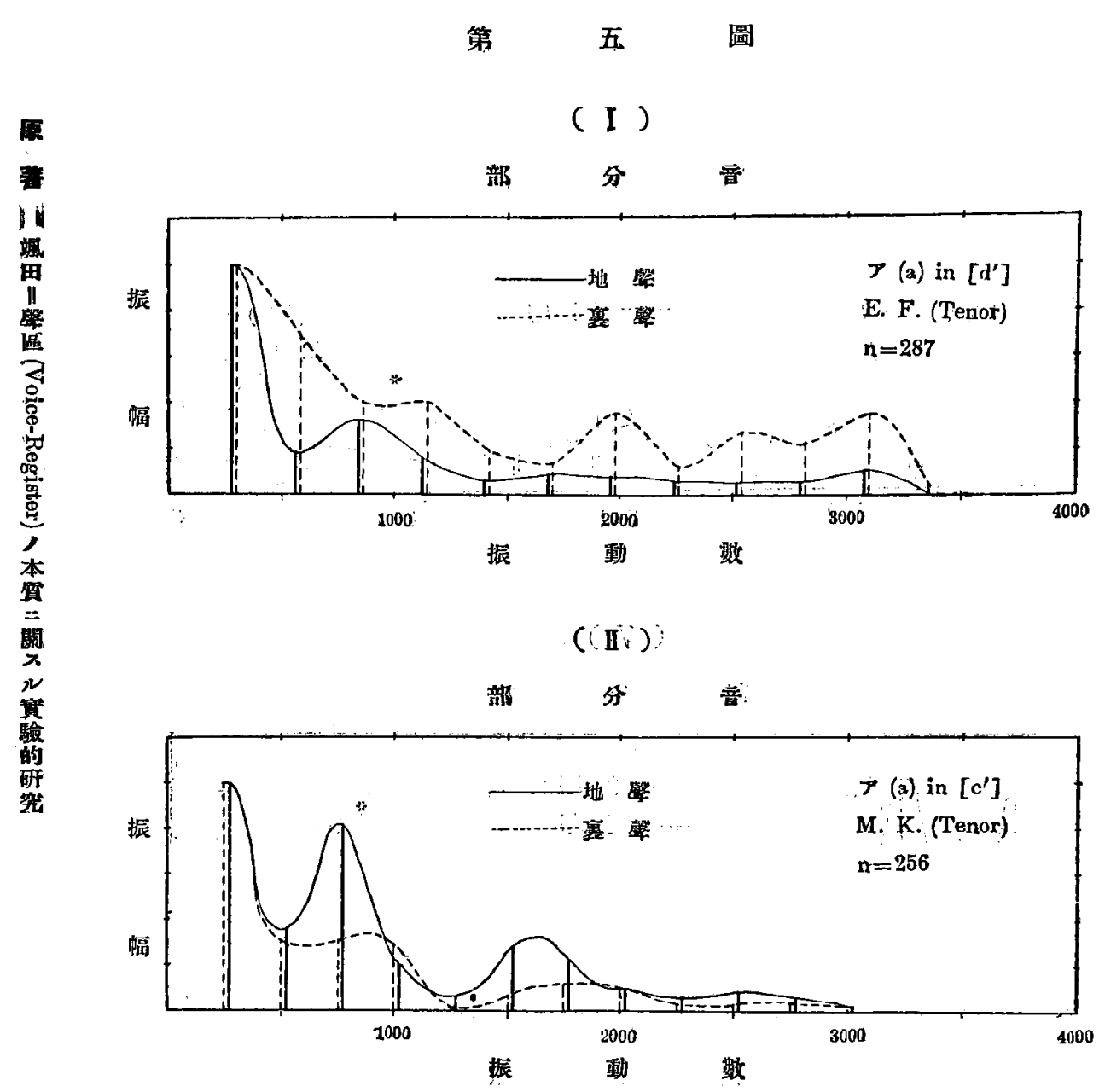

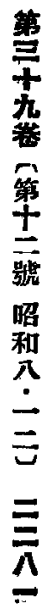

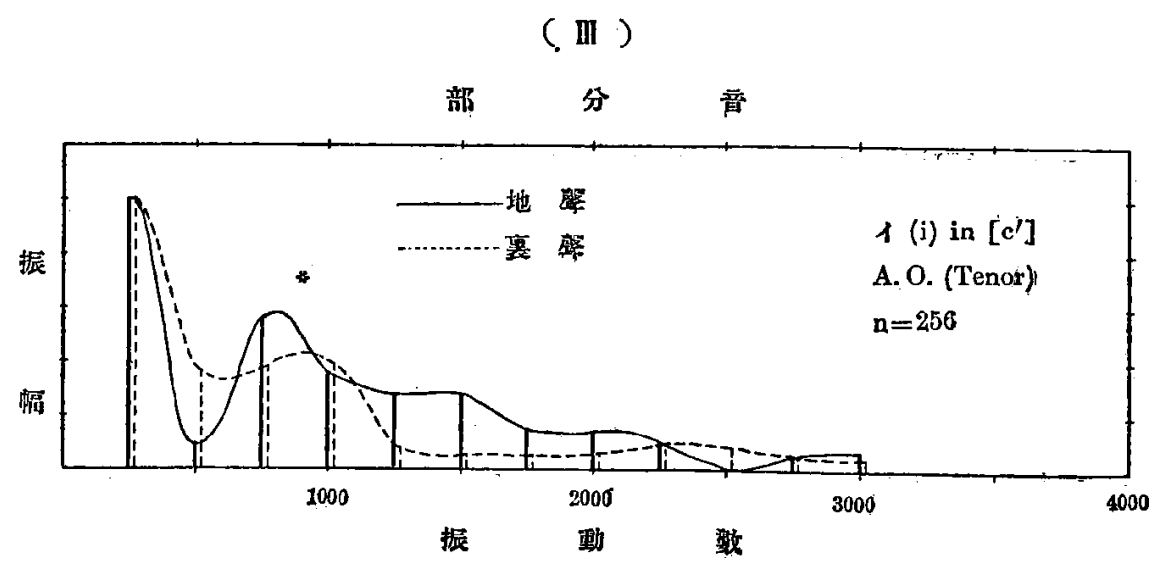


第五圖
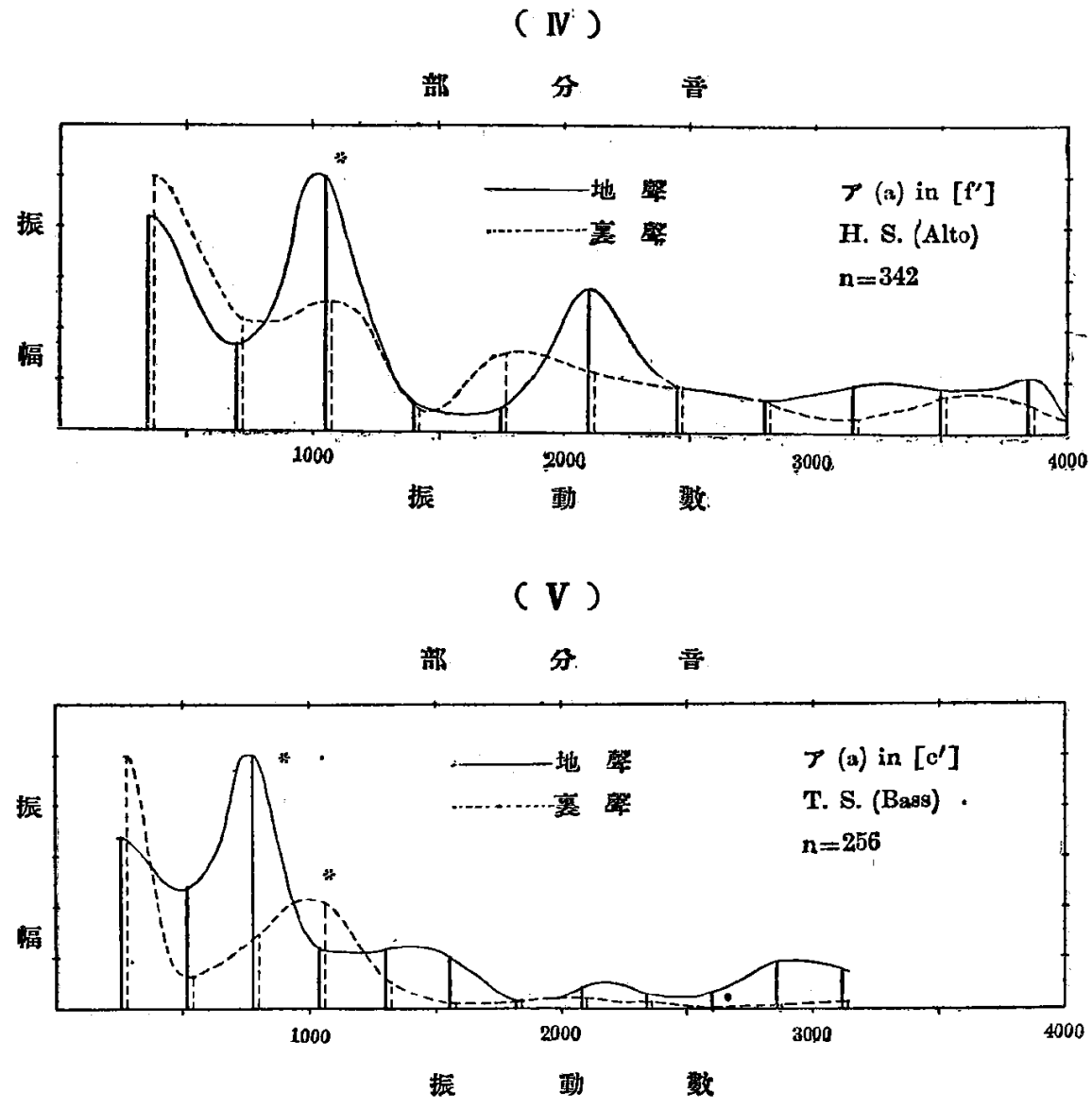

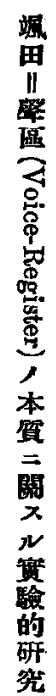

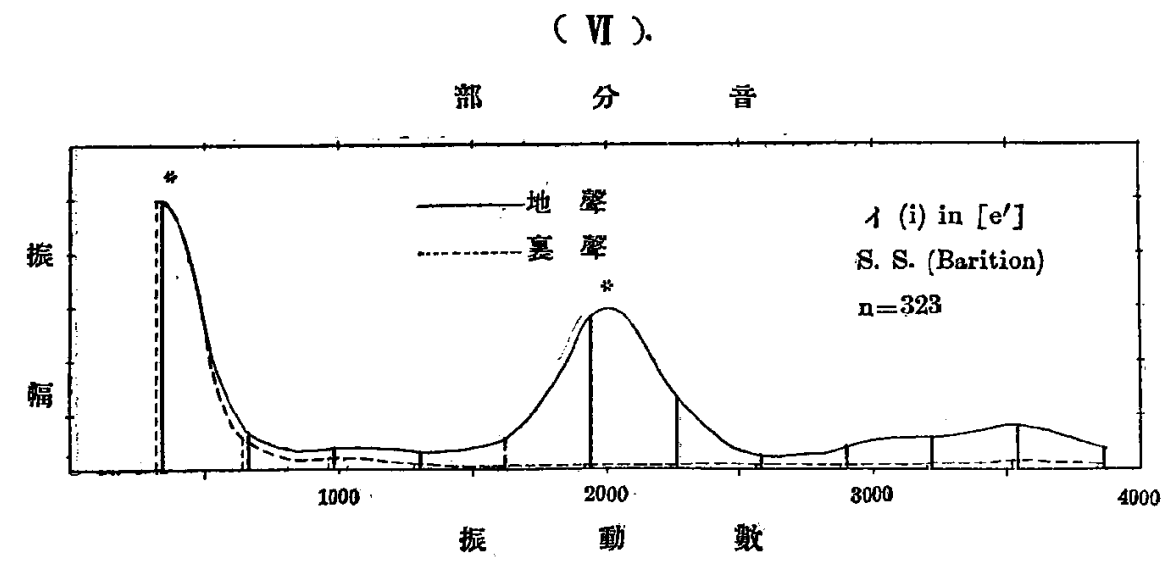

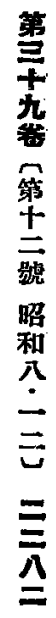




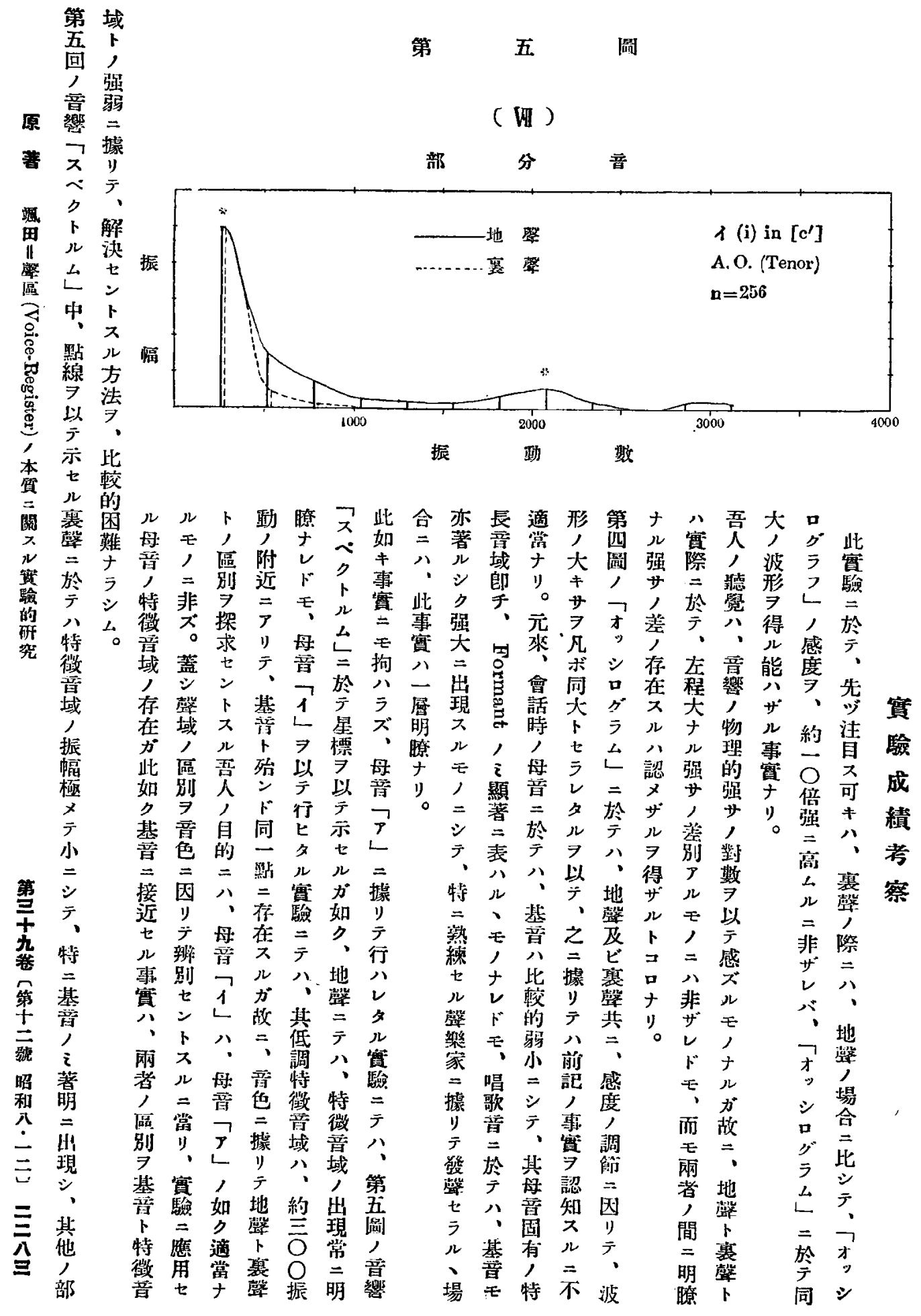




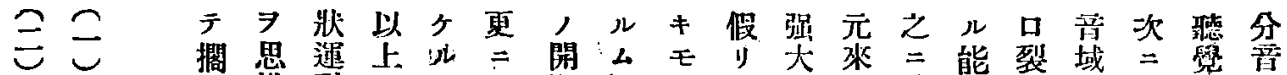

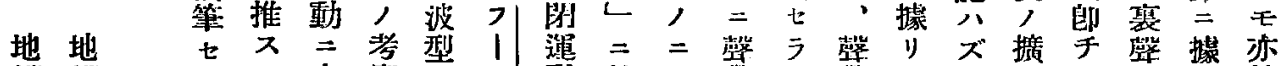

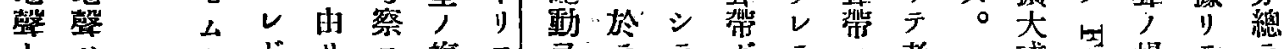

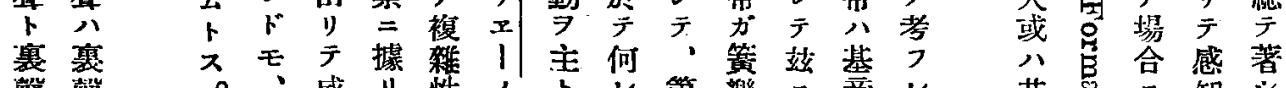

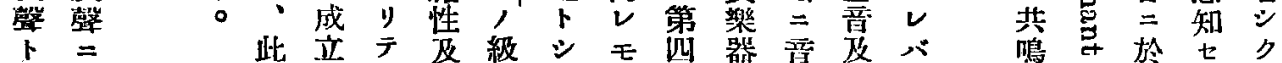

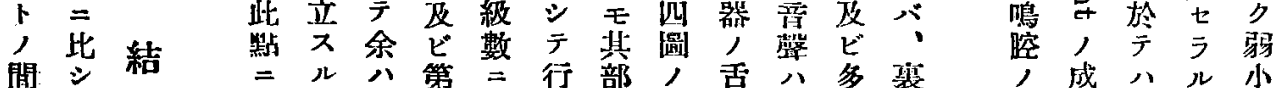

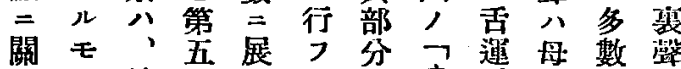

$=\bar{\tau}$

八振

倍幅

意遥

種 犬

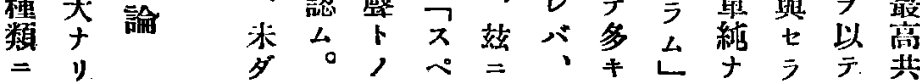

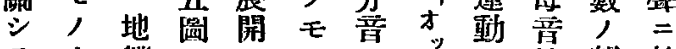
テナ薪, ス, , シ”, 性部於 余卡意レ卜極口如寻分ケ

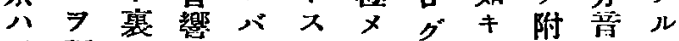
於。 等 系

統

的

差
7
J

正而孹ク極续結 $ニ ル$ 成鳴

確區卜女頭果示莲、㐬器 ナ之人ルテハョセ動モス。 儿等美么多此签儿, , 移

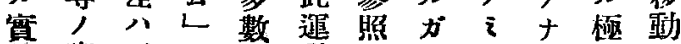
䮦事前云部動 根, 渚乡分由心゙複つ複成

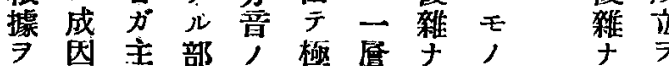

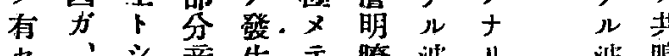

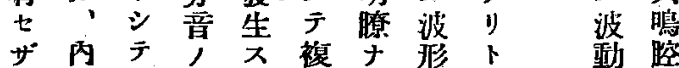

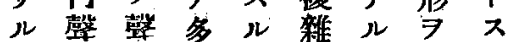

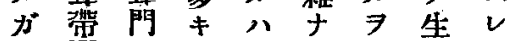

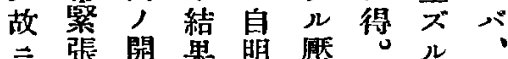

”張閶果明厴今ル

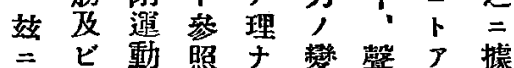

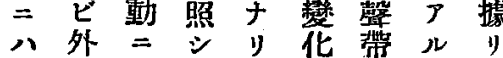
單薜由示、公可厅 此䉯

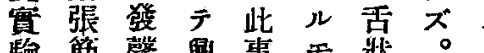

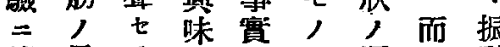
㨜異亏分二運王動 リナル 第 シ 動此波 テレ、問西示, 事形

得 $心=$ 題國i $i$ 筧八

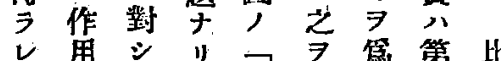

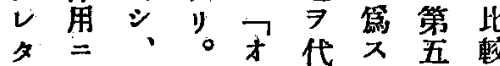

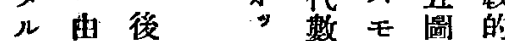

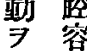

發 積

生渢

; 少

苏角

共 7

鳴

羫

通 》

過

觉

際

其至

闻 1

事々者 シ 第人, =

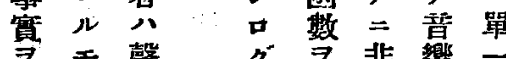

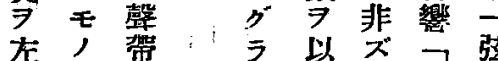

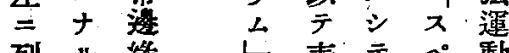

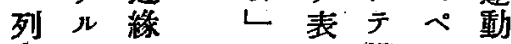

舉口, = 八㵨”

有

動

近

振

振

* p 古

於 シ 門

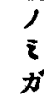

容立?ル小

珑

積 第トリ卧

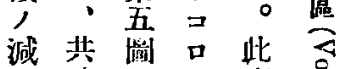

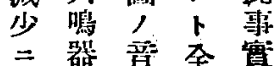

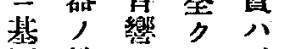

因 性 ᄀ -

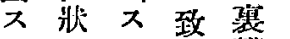
ル ペス壁

モ基 ク。另

, 因卜裳

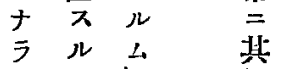

ザルム共

云 云 章

可 事依性

亏霓宁 失 研

ズ 明 ヒ 究

然 ぜカ 泚

共ル器

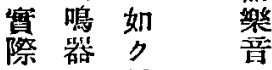

於一最离揞

テ般共近

八㭠鳴元

寒寻徽

整珍振 候

際 少數示

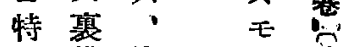

$=$ 篦比, 第

第

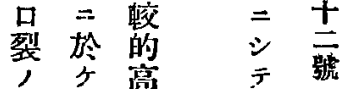

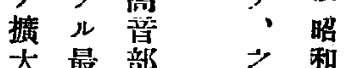

大最部学梨

ラ共移惯 三

、黑

害移蓋 吾 吾

認公特 今 


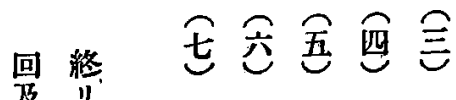

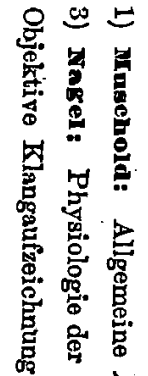

